\title{
THE EFFECTIVENESS OF USING COOPERATIVE LEARNING MODELS TOWARD PRE-SERVICE ELEMENTARY TEACHER'S UNDERSTANDING ON SOCIAL SCIENCE EDUCATION COURSE: A COMPARISON FOR COOPERATIVE SCRIPT, ARTICULATION, AND GUIDED NOTE TAKING
}

\author{
Eli Hermawati ${ }^{1}$, Mia Zultrianti Sari ${ }^{2}$, Yani Fitriyani ${ }^{3}$ \\ ${ }^{1,2}$ Pendidikan Guru Sekolah Dasar, Fakultas Keguruan dan Ilmu Pendidikan, Universitas \\ Kuningan, Indonesia \\ ${ }^{3}$ Pendidikan Dasar, Sekolah Pascasarjana, Universitas Pendidikan Indonesia, Indonesia \\ 1 eli.hermawati@uniku.ac.id, ${ }^{2}$ mia.zultrianti.sari@uniku.ac.id, ${ }^{3}$ yanifitriyani@upi.edu
}
Citation: Hermawati, E., Sari, M. Z., \& Fitriyani, Y. (2020). The effectiveness of using cooperative learning models toward pre-service elementary teacher's understanding on social science education course: a comparison for cooperative script, articulation, and guided note taking. Indonesian Journal of Elementary Teachers Education, 1 (1), 39-48.

Received: 05-03-2020 Accepted: 05-31-2020 Published: 05-31-2020

\section{ABSTRACT}

Our initial study in the course showed that there was a lack of students' understanding about social science. The purpose of this study was to investigated the effectiveness of using Cooperative Learning Model (Cooperative Script, Articulation, and Guided Note Taking) towards Pre-Service Elementary Teacher understanding on Social Science Course. This research was conducted in quasi-experimental research, with counterbalance research design. The subjects of this study were first year of undergraduate students of pre-service elementary school teacher education at the University of Kuningan. The data collection technique used was an instrument test which was an essay question. The data analyzed by statistical test with the t-test (independent samples t-test) at a $95 \%$ confidence level obtained $t_{\text {calc }}>t_{\text {table }}$ and probability value sig. $(2$-tailed $)<0.05$. The results of this study proved that there are differences in students' understanding so that the hypothesis is accepted. In our context, Cooperative Script was more sophisticated in improving student understanding compared to Articulation and Guided Note Taking. The limitation of our context means that there is no best method to be applied.

Keywords: understanding; cooperative script; articulation; guided note taking; pre-service elementary teacher 
Eli Hermawati, Mia Zultrianti Sari, \& Yani Fitriyani

THE EFFECTIVENESS OF USING COOPERATIVE LEARNING MODELS TOWARD PRE-

SERVICE ELEMENTARY TEACHER'S UNDERSTANDING ON SOCIAL SCIENCE

EDUCATION COURSE: A COMPARISON FOR COOPERATIVE SCRIPT,

ARTICULATION, AND GUIDED NOTE TAKING

\section{INTRODUCTION}

One way to improve the quality of human resources is to improve the quality of education. The initial step that needs to be done is to improve the quality of prospective educators. Through improving the quality of prospective educators, it is expected to be able to produce quality students too. The role of tertiary institutions as the frontline in creating professional educators certainly determines the success of improving the quality of their graduates.

The Faculty of Teacher Training and Education (FKIP), especially the PGSD study program (Pre-Service Elementary Teacher's), is one of the study programs that will produce prospective teachers who focus on providing knowledge, skills, attitudes to students in order to become prospective professional elementary school educators. As a prospective elementary school teacher, PGSD students are provided with various lecture materials that support teacher professional competence. As revealed by Wahyudi (2012: 31), professional competence is the ability of teachers to master learning material widely and deeply so that it is possible to guide and direct students to meet the expected competency standards.

Efforts to foster professional competence by equipping students with scientific material in elementary schools, one of which is a subject for elementary social studies learning materials. Social studies elementary school subject matter is a subject that discusses social science material taught at the elementary level. Study lectures are contextually ranging from the social environment that is closest to students to the global scope, social issues, and social phenomena that occur in people's lives.

Students before plunging into social science teaching practice in elementary school should have understood all social studies material so that they have a strong scientific background to be taught to students. But in reality, there are still many PGSD students in the understanding of social studies material is still low. This is indicated by the low value of midterm and final exam results in the Social Studies Basic Concepts course. From the results of the pre-research conducted by researchers, the results of the Mid-Semester Test (UTS) and Final-Semester Test (UAS) PGSD students who took the Basic Social Studies Subject were not optimal.

This is shown by the results of student learning, namely from 105 students as many as 46 students or $43.80 \%$ who achieved Minimum of Passing Grade Score (KKM) and while those who have not reached KKM were 59 students or $56.20 \%$. This shows that the learning outcomes of PGSD FKIP Kuningan University students still need improvement. According to Mulyasa (2005: 23), "learning can be said to be successful and quality if the majority or at least most (70\%). To solve the problem of the low level of understanding of students about the concept of social studies, lecturers as facilitators must find an effective learning model". One learning model that can be used to complete is by applying the Cooperative Learning model.

Cooperative learning developed from the theory of social interdependence from the theory put forward by Lewin. The behavior of group members is interactive so that they will achieve group goals effectively and efficiently if each member works together rather than working individually. The application of cooperative learning is expected to improve students' understanding of the material and learning motivation, which in turn can improve their achievement or learning outcomes.

Cooperative learning is one of the learning models that encourage students to be able to think in building an understanding. This is supported by research conducted by Sundari \& 
Andriana (2018: 114), Hakim, Taufik, \& Aini (2018: 83) who report the results of research that cooperative learning models are able to increase student understanding. In the cooperative learning model, there are various types of learning and researchers choose three learning models namely Cooperative Script, Articulation and Guided Note Taking learning models because these can form an understanding of learning from the results of discussions where student activities occur in multi-directional communication and encourage students to increase their collaboration in terms share thoughts or opinions.

Students who study through Cooperative Script will begin their working in pairs and take turns to summarize teaching material. An article must be read by each of them and they will be asked to argue new ideas. Each partner completes these new ideas (Alit, 2002: 203). According to Huda (2014: 268), Articulation is a learning model that the process takes place as a messaging game chain. It is mean that what the teacher has given must be continued by students by explaining to other students (pairs of groups). Finally, Guide Note Taking according to Silberman (2016: 123) asks students to learn using modified forms by the teacher. Students then make any notes about learning on it. These three types of learning models were chosen to be tested for their effectiveness in influencing students' understanding of concepts.

The existence of various learning models is expected to facilitate students' understanding of a particular material. Students' understanding of a material can be seen from students being able to understand and know about something and can see it from various aspects. A person can be said to understand something if he can provide an explanation or give a more detailed description of it by using his own words. According to Sapriya (2009), understanding is the ability to capture the meaning of a material that has been studied which is seen among others in interpreting information and predicting the consequences of an event. Relevant to "ability", explained by Uno \& Mohamad (2015: 56) that the ability at the level of understanding includes the ability to classify, describe, discuss, explain, express, define, show, allocate, report, acknowledge, review, select, state, and translate. Based on the problems in this background, the effectiveness of several types of cooperative learning models was tested toward students' understanding of concepts. Therefore, this research was feasible.

\section{RESEARCH METHOD}

\section{Research Design}

The research design is related to the method and the reason why the method is used in research (Sugiyono, 2015: 205). This research conducted in quasi-experimental study by implementing the counterbalanced design. The research team initiated a comparison between types of cooperative learning models to test the effectiveness of understanding. Instead of one test, we treat each subject with three types (Cooperative Script, Articulation, and Guided Note Taking) alternately. For example, In Time 1 we used Articulation to Subject 1; Cooperative Script to Subject 2 and Guided Note Taking to Subject 3. In Time 2, we shift the treatment to different subjects; Articulation to Subject 3, etc. We make sure that all of the subject groups get all types of treatment.

Table 1. Counterbalanced Design

Fraenkel (2012: 257)

\begin{tabular}{lllllll}
\hline Class A & X1 & O1 & X2 & O2 & X3 & O3 \\
\hline Class B & X2 & O2 & X3 & O3 & X1 & O1 \\
Class C & X3 & O3 & X1 & O1 & X2 & O2 \\
\hline
\end{tabular}


Note.

$\mathrm{X}_{1} \quad$ : Use of Cooperative Script

$\mathrm{X}_{2} \quad$ : Use of Articulation

$\mathrm{X}_{3} \quad$ : Use of Guided Note Taking

$\mathrm{O}_{1,2,3}$ : Final test in the experimental group

Convenience or accidental sampling technique wa used to identify the participants of the study. It is commonly used by researchers from different disciplines including medicine, psychology and other diciplines. In this technique participants are not chosen randomly. Instead the sample is drawn from the part of the population which is close to hand. That is, a population is selected because it is readily available and convenient.

The participants of the study was carried out at $1^{\text {st }}$ year undergraduate students of preservice elementary teacher eduacation program in Universitas Kuningan. The participants of this study were 105 undergraduate students.

Table 2. Research Subject

\begin{tabular}{|c|c|c|c|c|}
\hline \multirow[t]{2}{*}{ Class } & \multirow[t]{2}{*}{ Students } & \multicolumn{3}{|c|}{ Information } \\
\hline & & Study 1 & Study 2 & Study 3 \\
\hline Class A & 35 & Articulation & $\begin{array}{c}\text { Cooperative } \\
\text { Script }\end{array}$ & $\begin{array}{c}\text { Guided } \\
\text { Note Taking }\end{array}$ \\
\hline Class B & 35 & $\begin{array}{c}\text { Cooperative } \\
\text { Script }\end{array}$ & $\begin{array}{c}\text { Guided } \\
\text { Note Taking }\end{array}$ & Articulation \\
\hline Class C & 35 & $\begin{array}{l}\text { Guided Note } \\
\text { Taking }\end{array}$ & Articulation & $\begin{array}{c}\text { Cooperative } \\
\text { Script }\end{array}$ \\
\hline
\end{tabular}

\section{Data Collection}

The instrument used in this study is a test. Test instruments used posttest to measure students' understanding of Social Studies courses. The test is used to assess and measure the effectiveness of Cooperative learning models in the type of cooperative script, articulation and guided note taking towards students' understanding of the mastery of teaching materials in accordance with learning objectives. This test is used by researchers to obtain data and information about differences in student understanding by using three different treatments.

The form of the posttest given to each group of subjects every time is similar, the essay question. This essay question contains questions about understanding concepts in a social science education.

Data Analysis

Data obtained from research were processed and analyzed using statistic program named IBM SPSS version 22. The SPSS software package was used to assist in presenting data in percentages for analysis and discussion.

\section{RESULTS AND DISCUSSION}

\section{The Final Average of Student Ability}

Calculation of the average value and standard deviation is the first step for further testing. Testing the mean using raw data from the test results and measurements for each variable, comparison of post-test results from different methods and classes at each meeting 
where more details can be presented through the following graph. Graph 1 shows that the average scores in Study I, Study II, and Study III are different in each treatment.

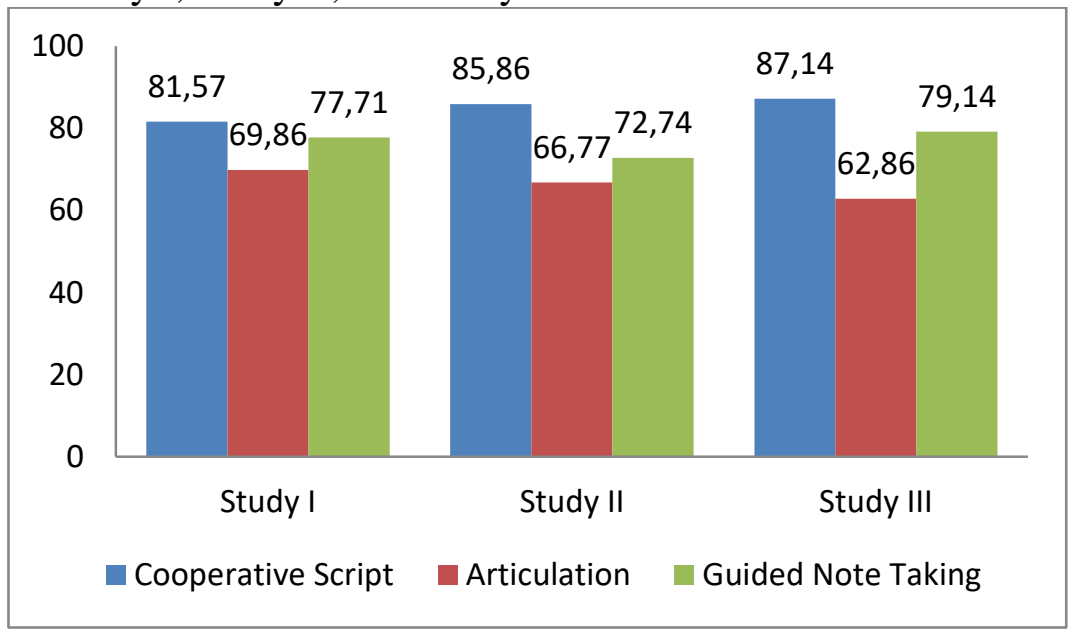

Graph 1. Comparison of Post-Test Result

\section{Normality Tests}

Normality distribution testing is performed on the final test results, namely the results of the post-test understanding ability. This normality test is used to determine whether data is normally distributed or not. This normality test uses the help of SPSS version 22 by using $\alpha=$ 0.05 . Based on the results of normality testing using SPSS version 22 as shown in Table 3 above, it can be concluded that all post-test data are normally distributed and homogeneous so that they can be used as prerequisites for t-test data analysis.

Table 3. Normality Test Results

\begin{tabular}{llllll}
\hline No & Variabel & Statistic & df & Sig. & Information \\
\hline $\mathbf{1}$ & Articulation study I & 0,218 & 35 & 0,127 & Normal \\
$\mathbf{2}$ & Cooperative Script study I & 0,150 & 35 & 0,079 & Normal \\
$\mathbf{3}$ & Guided Note Taking study I & 0,150 & 35 & 0,052 & Normal \\
$\mathbf{4}$ & Cooperative Script study II & 0,149 & 35 & 0,200 & Normal \\
$\mathbf{5}$ & Guided Note Taking study II & 0,251 & 35 & 0,200 & Normal \\
$\mathbf{6}$ & Articulation study II & 0,175 & 35 & 0,171 & Normal \\
$\mathbf{7}$ & Guided Note Taking study III & 0,160 & 35 & 0,137 & Normal \\
$\mathbf{8}$ & Articulation study III & 0,114 & 35 & 0,115 & Normal \\
$\mathbf{9}$ & Cooperative Script study III & 0,248 & 35 & 0,058 & Normal \\
\hline
\end{tabular}

The use of learning models must be relevant to the learning material to be given. Learning materials have different levels of difficulty so models, techniques, methods, and strategies that are relevant to the characteristics of the material are needed. The use of relevant learning models and methods will certainly be directly proportional to the learning outcomes. Of course, good learning outcomes are contributions from the use of learning models and methods.

Analysis of the effectiveness of the models applied in each study that has been done shows that three classes as subjects in learning have a different effect on students' understanding ability. In studies I, II, and III always show that the Cooperative Script is more effective than the Articulation and the Guided Note Taking. These results are based on testing the average value of all students through the post-test that has been given. The following is a presentation of the post-test results of each treatment that has been carried out. able 4 shows 
that the value of the Cooperative Script is always higher in each study compared to the Articulation and Guided Note Taking. Then it is stated that the Cooperative Script is consistent in each study.

Table 4. Average Scores for Using The Learning Model

\begin{tabular}{|c|c|c|c|c|c|c|}
\hline \multirow{2}{*}{ No } & \multirow{2}{*}{ Model } & \multicolumn{3}{|c|}{ Study } & \multirow{2}{*}{ Amount } & \multirow{2}{*}{ Average } \\
\hline & & I & II & III & & \\
\hline 1 & Cooperative Script & 81,57 & 85,86 & 87,14 & 254,57 & 84,86 \\
\hline 2 & Articulation & 69,86 & 66,77 & 62,86 & 199,49 & 66,50 \\
\hline 3 & Guided Note Taking & 77,71 & 72,74 & 79,14 & 229,59 & 76,53 \\
\hline
\end{tabular}

The Effectiveness of Using Articulation Models on Cooperative Script Models

Based on the results of statistical testing with SPSS version 22 that has been done, the results show that there are significant differences between the ability of students understanding who use the Articulation and students who use the Cooperative Script. This can be seen based on the average value of the three models in studies I, II, and III listed in Graph 1. From the three studies that have done, the average score of students who use the application of Cooperative Script obtained 84.86, while Articulation obtained 66.50. From these averages, it is clear that there are differences in terms of average score of student, but the difference is not significant. To see whether there is a difference in the ability of understanding between students who get learning with the Articulation and the Cooperative Script, the two mean difference test is performed or what is known as the t-test. T-tests were performed on data obtained consecutively namely from study I, study II, and study III.

In study I, the average two difference test results obtained sig. (2-tailed) value of $0,000<0.05$, which means that there are significant differences between students who get learning by using the Articulation and the Cooperative Script. In Study II, the two difference test results obtained an average value of sig. (2-tailed) of $0,000<0.05$, which means that there are significant differences between students who get learning using Cooperative Script and Articulation. In Study III, the two difference test results obtained an average value of sig. (2-tailed) of $0,000<0.05$ which means that there are significant differences between students who get learning by using the Articulation and the Cooperative Script.

After knowing that there are significant differences and based on the average results of the post-test in Study I, II, and III, it turns out that students who use the Cooperative Script are better/superior when compared to students who use the Articulation. In addition, the use of Cooperative Script contributes to improving students' understanding ability by 18.36 from the Articulation.

The research result relevant to Indriani (2017). Her research show valid learning materials, activity on student-centered, teaching, and learning materialized well $(3,9)$. The result of students' concept comprehension has been analyzed by $\mathrm{N}$-Gain that shows improvement $(0,75)$, and students' misconception is decreasing. It can be said that the Cooperative Scripts learning materials are feasible, has influence, and can enhance the concept comprehension and significantly affect the elimination of students' misconception on Civic Education subject in Elementary School students.

The Effectiveness of Using Articulation Models on Guided Note Taking Models

Based on the results of statistical testing with SPSS version 22 that has been done, the results show that there are significant differences between the ability of students 
Indonesian Journal of Elementary Teachers Education (IJETE)

p-ISSN: 2615-2606 \& e-ISSN: 2615-7853

Volume 1, Number 1, May 2020

https://journal.uniku.ac.id/index.php/ijete

understanding who use the Articulation and students who use the Guided Note Taking. This can be seen based on the average value of the three models in studies I, II, and III listed in Graph 1. From the three studies that have done the average score of students who use the Guided Note Taking obtained by 76.53 and Articulation obtained 66.50. From the average, it is clear that there are differences in terms of the average score of students but the difference is not significant. To see whether there is a difference in the ability of understanding of students who get learning with the Articulation and Guided Note Taking, the two mean difference test or known as the t-test is conducted. T-tests were performed on data obtained consecutively namely from study I, study II, and study III.

In Study I, the two average difference test results obtained sig. (2-tailed) of $0.016<$ 0.05 , which means that there are significant differences between students who get learning using the Articulation and the Guided Note Taking. In Study II, the results of two difference test average obtained sig. (2-tailed) value of $0.010<0.05$ which means there is a significant difference between students who get learning by using the Articulation and the Guided Note Taking. In Study III, the results of the two average difference value of sig. (2-tailed) is 0.007 $<0.05$, which means that there are significant differences between students who get learning using the Articulation and the Guided Note Taking. After knowing that there are significant differences and based on the average post-test results in Studies I, II, and III, it turns out that students use the Guided Note Taking better/superior when compared to students who use the Articulation. In addition, the use of the Guided Note Taking contributed to the increase in students' understanding ability by 10.03 from the Articulation.

The result is relevant to Narjaikaew, Emarat, \& Cowie (2009). Their research show indicated that students who were involved in the Guided Note Taking performed better on the conceptual test than students who were not involved in this approach.

\section{The Effectiveness of Using Cooperative Script Models on Guided Note Taking Models}

Based on the results of statistical testing with SPSS version 22 that has been done, the results show that there are significant differences between the ability of students understanding who use the Cooperative Script and students who use the Guided Note Taking. This can be seen based on the average score of the three models in Study I, II, and III listed in Graph 1. From the three studies that have done the average score of students who applied Cooperative Script obtained 84.86 results, while Articulation obtained 66.50, and Guided Note Taking obtained 76.53.

From these averages, it is clear that there are differences in terms of average student grades, but the difference is not significant. To see whether there is a difference in the ability of understanding between students who get learning with the Cooperative Script and Guided Note Taking, the two average test is done or known as the t-test. T-test was performed on data obtained consecutively namely from Study I, Study II, and Study III. In study I, the results of the two difference test average obtained sig. (2-tailed) of $0.047<0.05$ which means that there are significant differences between students who get learning by using the Cooperative Script model and the Guided Note Taking model. In Study II, the two-tailed difference test results obtained a value of sig. (2-tailed) of $0.012<0.05$, which means that there are significant differences between students who get learning using the Cooperative Script and the Guided Note Taking. In Study III, the two-tailed difference test results obtained a sig. (2-tailed) value of $0.005<0.05$, which means that there are significant differences between students who get learning by using the Cooperative Script and the Guided Note Taking. After knowing that there are significant differences and based on the average results of the post-test in Study I, II, and III it turns out that students who use the 
Cooperative Script are better/superior when compared to students who use the Guided Note Taking. In addition, the use of the Cooperative Script model contributed to the increase in students' understanding ability by 8.33 from the Guided Note Taking.

\section{CONCLUSION AND RECOMMENDATION}

Based on the results of research conducted, Cooperative Script learning models are more effective in increasing student understanding compared to Articulation learning models and Guided Note Taking learning models. This means that when learning students are more enthusiastic in participating in learning activities students can actively discuss and ask questions in more advanced learning here shows the quality of learning that uses Cooperative Script learning models more effectively can improve the understanding of PGSD level 1 students in social studies subjects.

The application of learning methods that are tailored to the needs and teaching material that must be discussed. There is no best method to be applied, all methods will be effective if it is adjusted to the agreed learning objectives and the teaching materials provided. 


\section{REFERENCES}

Alit. M. (2002). Pembelajaran kooperatif. Cirebon: Media Persada.

Fraenkel, Jack R. (2012). How to design and evaluate research in education 8th ed. New York: McGraw-Hill.

Hakim, Zerri Rahman., Taufik, \& Aini, Qurrotul. (2018). Penerapan model pembelajaran cooperative learning tipe talking stick terhadap pemahaman konsep kegiatan jual beli pada mata pelajaran IPS kelas III sekolah dasar. Jurnal Pesona Dasar, 6 (2), 75 84.

Huda, Miftahul. (2014). Model-model pembelajaran dan pembelajaran isu-isu metodis dan paradigmatis. Yogyakarta: Pustaka Pelajar

Indriani, Dian Eka. (2017). Cooperative script model in civic education for elementary school students. HUMANIORA, 8 (2), 105-112.

Mulyasa, E.. (2005). Menjadi guru profesional menciptakan pembelajaran kreatif dan menyenangkan. Bandung: PT. Remaja Rosdakarya.

Narjaikaew, Pattawan., Emarat, Narumon., \& Cowie, Bronwen. (2009). The effect of guided note taking during lectures on Thai university students' understanding of electromagnetism. Research in Science \& Technological Education, 27 (1), 75-94.

Sapriya. (2014). Pendidikan ips: konsep dan pembelajaran. Bandung: PT. Remaja Rosdakarya.

Silberman, Melvin. (2016). Active learning: 101 strategi pembelajaran aktif. Bandung: Nuansa Cendekia.

Sugiyono. (2015). Metode penelitian pendidikan. Bandung. Alfabeta.

Sundari, Kori., \& Andriana, Septian. (2018). Upaya meningkatkan pemahaman konsep siswa melalui model artikulasi pada mata pelajaran ips di kelas V SDIT An-Nadwah Bekasi.PEDAGOGIK, 6 (2), 109-116.

Uno, H. B. \& Mohamad, N. (2015). Belajar dengan pendekatan pailkem. Jakarta: Bumi Aksara.

Wahyudi, Imam (2012). Mengejar profesionalisme guru: strategi praktis mewujudkan citra guru profesional. Jakarta: Prestasi Pustaka. 
Eli Hermawati, Mia Zultrianti Sari, \& Yani Fitriyani

THE EFFECTIVENESS OF USING COOPERATIVE LEARNING MODELS TOWARD PRESERVICE ELEMENTARY TEACHER'S UNDERSTANDING ON SOCIAL SCIENCE EDUCATION COURSE: A COMPARISON FOR COOPERATIVE SCRIPT, ARTICULATION, AND GUIDED NOTE TAKING 